\title{
A compromise of rights, rights of language and rights to a language in Eugene Terre'Blanche's (ET) trial within a trial: evidence lost in translation
}

Monwabisi Knowledge Ralarala

Fundani Centre for Higher Education Development, Cape Peninsula University of Technology, 1906 Bellville, South Africa

E-mail: RalaralaM@cput.ac.za

\begin{abstract}
The trial (within a trial) of Eugene Terre'Blanche (hereon referred to as the ET Trial) in a high court, which took place in Ventersdorp in January and February 2010 sparked intense interest in South Africa and abroad, and raised critical questions about issues of (i) language rights, (ii) communicative competence of law enforcement agencies, particularly the police, and (iii) the asymmetries in the police interaction with the accused persons. Apart from communicating the rights of the accused persons in a language that $\mathrm{s} / \mathrm{he}$ understands, the police officers are entrusted with additional responsibilities which include, among others, being a channel or conduit that encodes and decodes information within milliseconds in an attempt to reconstruct an accused person's narrative into formal evidence for purposes of court proceedings. This reality is further substantiated by Komter (2002/2003:202) who suggests that, "[...] police officers should record the fact that they informed the suspect about his right to silence and [...] that they record the suspect's statement as much as possible in his own words". Against this backdrop, it is also worth stating that the South African multilingual setting is confronted by serious complexities, especially in cases where the accused is a speaker of an African language who can only rely on interpreting/translation services in order to follow the legal discourse, whereas languages of record are still solely in English and Afrikaans. Based on an examination and analysis of the judgement of the ET trial within a trial, this study finds that, despite the dawn of democracy, the South African Criminal Justice System is still confronted by linguistic and cultural challenges. Central to these challenges is the potential for miscarriages of justice. Furthermore, the main principles of Critical Sociolinguistic Analysis (CSA) employed in this study have uncovered the fact that power imbalances in the criminal justice system do not necessarily originate through legislation but through situated processes and practices (Eades 2010). As Fairclough appropriately argues, there is a need not just to examine the power in the discourse but also the power behind the discourse (1989).
\end{abstract}

Keywords: language rights; communicative competence; asymmetry; transpreters; trial within a trial

\section{Introduction}

Law is made possible by language. Crime is part and parcel of the human condition and, as such, communication constitutes a fundamental part of the criminal process (Waterhouse 2009). In South Africa, an encounter with officers at a local police station with the intention to lay criminal charges is a classic example of a language event which connects language, law and crime. This is one of the fundamental components of the administration of criminal justice that 
initiates the court process made possible by translated sworn statements taken from members of the public (translated mostly from African languages into English and, in some cases, Afrikaans), and culminating in court as evidence for proceedings (Geldenhuys 2001). This important aspect of the law is often underestimated and regarded as a simple and straightforward task. However, the actual translation of a police-sworn statement as a reconstruction of the complainant's oral narrative has serious, far-reaching implications when such translation involves witnesses that come from different cultural and linguistic backgrounds, not only for the complainant and the perpetrator but also for law enforcement personnel or police officers (hereafter referred to as transpreters) who might find it difficult to gather evidence as a result of language barriers. My reason for coining and using the term "transpreters" to address the designated police officers is informed by the type of dual dramatic competence and performance required - on the job - in order to render the cognitive and social service of message production and reception within the framework of both translation and interpreting of sworn statements. I will return to this issue later in the discussion.

Existing literature shows some differences and inconsistencies in relation to the oral narratives and translated versions presented in English and, in some cases, Afrikaans (State (S) v Kimbani 1979 (3) SA 339 (E)); (S v Mahlangu and Ndlovu 2010 (2) SA CC70). Komter (2002/2003) points out that sworn statements are supposed to be written down as far as possible in the suspect's (or complainant's) own words. However, these sworn statements tend to be the police officers' written versions of what was initially said during the interview. The problem of language barriers is not unique to South Africa; it is a problem of multilingual and multicultural societies around the globe. It has been well documented in Australia (cf. Cooke 1995), in the United States (cf. Shah, Rahman \& Khashu 2007), Ireland (cf. Waterhouse 2009) and elsewhere. What makes South Africa more peculiar are the human costs that are presented by this challenge in real life situations, including sentencing people to imprisonment, sometimes for crimes they did not commit. A case in point relates to a High Court case presided over by Judges J.P. Cloete and J. Kannemeyer J (cf. S v Kimbani 1979 (3) SA 339 (E)). This case was based on coercive police interrogation to obtain evidence during statement taking from the accused. The accused, in this case, testified that he never said what was contained in the evidence but the police physically attacked him and he was forced to sign the statement. Charged with statutory and common law perjury in a Magistrate court, the isiXhosa-speaking accused gave evidence through an interpreter, was found guilty, and was charged with a sentence of 12 months' imprisonment. Notably, upon review, the evidence of the interpreter (not of the accused) was recorded - deemed to be correct and proper by the court - thus elevated to proof beyond a reasonable doubt. The conviction was confirmed by the judge but the sentence was reduced to six months' imprisonment, presumably due to mitigating circumstances in that the accused was young ( 23 years of age) and had no previous criminal record.

Language and the law seem to be related fields of interest and study in South Africa, although not blossoming as much as one would imagine given the controversial official state of the indigenous languages in the various domains. Nevertheless, the interface of language and the law has received considerable attention as an area of study in the international community. The scholarly interest in linguistic and legal phenomena across the globe has assumed the study of forensic linguistics (Shuy 2007; Eades 1996, 1997, 2004, 2010, Coulthard \& Johnson 2007; Linfoot 2007; Moeketsi 2002; Lubbe 2008; Shah, et al. 2007; Berk-Seligson 2008; Rock 2007, and Kaschula \& Ralarala 2004). Shuy (2007:101) defines "forensic linguistics" as language used in trials by judges, lawyers and witnesses; the language of the law itself; the language used in civil cases, and the language used in criminal cases. Furthermore, Eades (1997) sheds some 
light with regard to the scope covered in the area, and points out that the interface between language and the law has mainly been covered by the following areas (the last two of which are central to this article):

(i) Speaker identification - the phonetic analysis of voices of people who make threatening phone calls;

(ii) Tape transcription - focusing on disputes that might arise over tape recordings of interviews with the police;

(iii) Alleged verbal examination of disputes over fabricated records and contested authorship of texts;

(iv) Cross-cultural communication differences - consideration of issues relating to language and cultural differences that tend to disadvantage primarily speakers of African language, when embroiled in a 'foreign' criminal justice system, as their English proficiency is low or non-existent; and

(v) Comprehension - examination of the extent to which accused persons or witnesses may have not understood the police caution or questions during the interview.

Drawing primarily on the issues of cross-cultural communication and comprehension, and through examining the judgement of the ET trial within a trial, this article aims to address the following questions:

(i) Do language rights remain myths or are they a reality in the South African judiciary?

(ii) Can the police officers fulfill their role competently as transpreters?

(iii) What asymmetric role do police officers occupy in handling language events relevant to their duty?

(iv) What are the implications of the ET trial within a trial in the context of law enforcement in South Africa?

From a theoretical standpoint, the research reported in this article is rooted in the Critical Sociolinguistic Approach (CSA). Systematic work has been carried out using this approach with specific reference to the Aboriginal people and the criminal justice system (Eades 2004, 2010). CSA includes both micro and macro analysis; the former being language use, discourse, etc., and the latter being concerned with issues of power, dominance and inequality in Van Dijk's (2003) terms. The ET judgement is central to this investigation particularly with regard to the micro analysis, as this is the analysis of the wider power struggles that involve speakers of African languages who sometimes find themselves embroiled in criminal activities, whose English and Afrikaans proficiency is low or non-existent.

\subsection{Sociolinguistic principles relevant to the legal set-up}

Eades (2010:5) defines "sociolinguistics" as a discipline that is concerned with the complex relationship between language and society. She further points out three main ways in which this relationship could be conceptualised. Firstly, language reflects society. Such an assumption would view the hierarchical ways of addressing participants in the courtroom environment. Simply put, this relates to the reflection of the authority and power relations within the court environment. Referring to the judge or the magistrate as "My Lord" is a classic example of this hierarchical situation. 
Secondly, language determines society or aspects thereof, or culture or thought for that matter. This assumption, according to Eades (ibid), "reverses the direction of the relationship between language and society, so that the hierarchical authority structure in the courtrooms would be seen partly as the effect of such language usage". It is worth stating that this second position on language and society points aptly to the notion of 'linguistic determinism' which highlights the fundamental differences that separate speakers of various languages, such as the Eskimos who are said to have "[...] eighty-seven words for snow and not one for malpractice" (Adler \& Rodman 2006:106). The most well-known theory that has dealt with linguistic determinism is the Whorf-Sapir/Whorfian hypothesis.

Thirdly, language concurrently reflects and shapes society. This third sociolinguistic assumption seems to be the most favoured, and thus forms the basis for a reciprocal relationship between language and society. Eades (2010:5) asserts that "this axiomatic understanding of society underpins the best sociolinguistic work on language in the legal process". This view is supported by Kaschula and Anthonissen (1995:83) who suggest that a broad sociolinguistic framework which draws on both ethnographic and ethno-methodological principles bears much more relevance when dealing with issues of language and the law. The ET trial and judgement seems to be one of the classic examples that provides, from a broad sociolinguistic perspective, practical situations upon which legal recognition of both linguistic and cultural differences, balance of power and rethinking of record construction by the police, should be advocated.

\section{The facts about the case and the judgement}

The two accused persons, Chris Mahlangu (Accused 1) and Pembi Patrick Ndlovu (Accused 2), were charged with housebreaking with intent to rob and robbery with aggravating circumstances, murder and attempted robbery with aggravating circumstances. It was alleged that on the $3^{\text {rd }}$ of April 2010 at or near Witrandjiesfontein Farm, Ratzegaai, in Ventersdorp, the two accused broke into the house of the deceased, Eugene Nay Terre'Blanche (ET), robbed him of his Nokia cell phone, murdered him and attempted to rob him of his white Opel Corsa motorvehicle. The state alleged that, at all material times, the accused acted with a common purpose. The accused pleaded guilty to all of the charges. The trial was conducted in camera, the reason being that Accused 2 was still a minor. It is also true that the trial attracted immense media interest, both locally and abroad, by virtue of the deceased's close connections with the Afrikaanse Weerstandsbeweging (AWB). The cause of death contained in the post-mortem report was described as "blunt-force head, chest and neck trauma". The AWB (translated as the Afrikaner Resistance Movement) was formed by Eugene Terre' Blanche in 1973 as a South African far-right political and paramilitary organisation. Its Afrikaner nationalism ideology and the establishment of an independent Boer-Afrikaner republic (what was commonly known as the "Volkstaat") as part of South Africa, was always part of its main agenda.

\subsection{Synopsis of the order by the judge ${ }^{1}$}

Accused 1, Chris Mahlangu, was found guilty as charged. In terms of Accused 2, Pembi Patrick Ndlovu: In respect of Count 1: Housebreaking with intent to rob and robbery - he was found not guilty, but found guilty of housebreaking with intent to steal. With reference to Count 2: Murder - he was found not guilty. In respect of Count 3: Attempted robbery - he was found not guilty.

\footnotetext{
${ }^{1}$ Justice John Horn: High Court of South Africa, South Gauteng
} 


\section{Analysis of selected extracts from the judgement}

In order to echo and demystify the focus of the issues that relate to (i) language rights in the criminal justice system; (ii) the asymmetric role of the police and (iii) the communicative competence of transpreters, this paper takes the angle of critically examining the lengthy commentaries contained in the judgement as cited by Judge John Horn, his detailed explications and implications of the circumstances surrounding the case, and his ultimate delivery of the judgement.

\subsection{Language rights in the criminal justice system: prospects and constraints}

In terms of the Constitution (Chapters 1 and 2, Sections 6 and 35, Constitution of the Republic of South Africa 1996), critical provisions that relate to language rights are cited. Geldenhuys contextualises these constitutional provisions within the criminal justice system when noting the challenges facing the system: (i) the fact that the police service must meet the constitutional requirements when communicating internally, as well as when dealing with the public whom it serves; (ii) the fact that the functions of the police service form an essential part of the administration, and as such the administration produces and packages documentation that is required for court purposes; (iii) the fact that the Constitution requires that arrested, detained and accused persons be informed of their rights in terms of the Constitution in the language that they understand (2001:135).

According to Van der Merwe and Van der Merwe (2006:15), South Africans speak the following languages:

Table 1. Language composition of South Africa

\begin{tabular}{|l|l|l|l|l|l|}
\hline \multirow{2}{*}{ Language } & \multicolumn{2}{|c|}{$\mathbf{1 9 9 1}$} & \multicolumn{2}{c|}{$\mathbf{2 0 0 1}$} & \\
\cline { 2 - 6 } & Numbers & Percentage & Numbers & Percentage & $\begin{array}{l}\text { Total } \\
\text { Numbers }\end{array}$ \\
\hline isiZulu & 8343590 & 22.1 & 10677306 & 23.8 & 2333716 \\
\hline isiXhosa & 6646568 & 17.6 & 7907154 & 17.6 & 1260586 \\
\hline Afrikaans & 5702535 & 15.1 & 5983426 & 13.3 & 280891 \\
\hline Sepedi & 3530616 & 9.4 & 4208982 & 9.4 & 678366 \\
\hline Setswana & 3482657 & 9.2 & 3677016 & 8.2 & 194359 \\
\hline English & 3414900 & 9.1 & 3673197 & 8.2 & 258297 \\
\hline Sesotho & 2420889 & 6.4 & 3555189 & 7.9 & 1134300 \\
\hline Xitsonga & 1439809 & 3.8 & 1992207 & 4.4 & 552398 \\
\hline siSwati & 952478 & 2.5 & 1194428 & 2.7 & 241950 \\
\hline Tshivenda & 673540 & 1.8 & 1021759 & 2.3 & 348219 \\
\hline isiNdebele & 477895 & 1.3 & 711818 & 1.6 & 233923 \\
\hline Other & 630927 & 1.7 & 217297 & 0.5 & -413630 \\
\hline Total & $\mathbf{3 7 7 1 6 4 0 4}$ & $\mathbf{1 0 0 \%}$ & $\mathbf{4 4 ~ 8 1 9 7 7 9}$ & $\mathbf{1 0 0 \%}$ & $\mathbf{7 1 0 3 3 7 5}$ \\
\hline
\end{tabular}

Table 1 might be somewhat outdated by a little more than a decade in terms of the South African language scenario, but the reality in 2012 probably does not show any significant difference, especially when one takes a closer look at the trends between 1991 and 2001. Essentially, almost 70 percent of South Africans are speakers of African languages or have an African language as their mother tongue. By contrast, only approximately 30 percent are speakers of either Afrikaans or English or have Afrikaans or English as their mother tongue. The rest, accounted for in the 'Other' category, comprises languages such as German, Portuguese, 
Mandarin, Greek, Hindu, Italian, etc. The point being made here is that a significant percentage of South Africans (constituting almost 70 percent) are not conversant in the language of the criminal justice system, that is English and Afrikaans, and it is unlikely that this figure will change dramatically in the near future. The reality of this situation is unsustainable and unbearable in the new dispensation. Further exacerbating the problem is the fact that English and Afrikaans have remained permanently unshaken, with African languages totally excluded, even post 1994. It is also worthy to note that the maintenance of the status quo is vindicated by issues of practicality and costs, and such constraints, in my view, are unjustifiable considering the present language configuration. The status quo is thus nothing short of continued inequality and discrimination in South Africa.

According to Makoni, Watson, Pienaar and Moyo (2008:5), "the right of language refers to the right of each individual language to exist and the equality of opportunity for it to develop. The right to language functions at an individual level. It refers to the rights an individual has to taking part in a court hearing in a language of their choice". The problem of compromising language rights is even more prevalent and serious in the domain of law enforcement, mainly in police stations, where evidence is first initiated. Further complicating the issue is the fact that speakers of African languages hail from a rich cultural background and heritage and, as such, this human peculiarity involves a somewhat unique structure of thinking and a variety of communication patterns that are influenced by particular speech acts, which are different from the native speakers of other languages such as English and Afrikaans.

Apart from the Constitution, a number of concerted efforts (borne out of the Constitution) towards obtaining linguistic rights in South Africa have been embarked upon, including the establishment of the Pan South African Language Board through an Act of Parliament, Act 59 of 1995; and the establishment of the Commission for the Promotion and Protection of Cultural, Religious and Linguistic Rights of Communities through an Act of Parliament, CRL Rights Act 19 of 2002. Underlying these political initiatives was a desire to reclaim, develop, protect and promote all diminished and diminishing heritage associated with the afore-mentioned establishments. Despite these efforts, along with precious time and resources invested, a generic survey revealed continued minimal achievements in the direction of language development and multilingualism in South Africa, and the criminal justice system is a case in point (cf. Cote 2005). Berk-Seligson (2008:12) elaborates when equating this hopeless situation (although describing the situation in Ecuador) to an "[...] outmost universal lip-service support for the right of indigenous peoples to use their ancestral languages in judicial contexts". However, it is worth mentioning that the South African Languages Bill (2011), currently tabled in Parliament, with its ambitious objectives and application could be South Africa's last attempt that could (only if equipped with independent powers and enforcement mechanisms) stand the test of time and win the battle for language rights. Once the proposed legislation is ratified, it remains to be seen how its implementation will unfold.

To flesh out the notion of compromising of rights in relation to the ET trial, reference is made to the judgement:

\section{Extract 1}

The details which Lt Col Jacobs supplied to Accused 2 and his mother were interpreted to them in Setswana. The undisputed evidence of $\mathrm{Lt}$ Col was that where the wording was somewhat complicated he explained the meaning and import thereof in broader terms. This was 
confirmed by Reserve/Constable Mthembu, the interpreter. Reserve/ Constable Mthembu stated that he interpreted from Afrikaans to Setswana and vice versa. At no stage did either Accused 2 or his mother complain that they did not understand him or that they did not understand the proceedings (2010:26).

\begin{abstract}
Extract 2
It is evident that when Lt Col Mano initially interviewed Accused 2, he did so without his mother being present. It was in fact during this time that Lt Col Mano elicited from Accused 2 certain admissions and his willingness to do a pointing out. Explaining such procedure and particularly the possible implications thereof to a practically illiterate boy of not quite 16 years of age is meaningless. This is such a serious case and the implications for Accused 2 are so crucial, that surely his ability to understand and appreciate what he was in for should have received more consideration and attention from the police. Moreover, to talk to his mother about these things, a woman who allegedly is illiterate and afflicted with a serious drinking problem, certainly did not help matters. Did Accused 2 and his mother really understand what was going on? I seriously doubt it (2010:28-29).
\end{abstract}

From the cited Extract 1, it is apparent that the type of information transfer leaves a lot to be desired, as revealed by the judge in Extract 2. Whether this situation, as it is, might have influenced the outcome of the case in favour of the accused person/s or the state, remains a controversy. Scholars (Moeketsi 2002, Eades 2010, Hussein 2011) who have extensively investigated this problem, shed some important light on the issue. They all concur that suspects who are provided with non-partisan, unqualified, untrained interpreters/translators, can bear serious implications for the practice, and as such this type of malpractice has the potential for miscarriage of justice. It is worth mentioning that this type of malpractice in the criminal justice system has a long history in South Africa, dating as far back as the apartheid era. Furthermore, as much as the judge's perspective in Extract 2 is somewhat akin to the arguments advanced in this paper, this position does not necessarily address the linguistic and cultural challenges that confront the system. Instead, it perpetuates what Eades (2002:175) perceives as police power over members of the public, especially the illiterate. And this power or dominance is not only localised in the actions of the police officers, but also in the legal system which gives its consent and acceptance of police action as commonsense. Central to this consent is the use of unreliable and problematic linguistic practices and assumptions which enable the state to legitimise police actions (ibid). Arguably, this possible subverting of the intent of the law rests, to a greater extent, upon the manipulation of language use, particularly English and Afrikaans, with the total exclusion of African languages and those who speak them. Thus, it could be argued that the entire case amounts to nothing but "reproduction of inequalities [...] and blatant abuse of power" (Eades 2010:241). Whether this situation might have influenced the outcome of the case in favour of the accused person/s or the state, remains a controversy. Of note is that language rights in the criminal justice system are characterised by constraints and, as such, the exercising of such rights for those whose English and Afrikaans proficiency is low or non-existent seems wholly Utopian. For this reason, lack of effective communication with the accused person - as has been the case in the ET trial - compromises the fundamental principle of a fair trial, and can possibly affect the delivery of justice. 
This paper also argues and advocates that part of the mechanism that could be put in place within which South African indigenous languages could be recognized and protected in the legal sphere is through their equation with human rights in South Africa. In pursuit of this position, the author embraces the view submitted by Karton $(2008: 10)$ that being able to exercise your (language) right entails, amongst others, due process rights. The simple reference to this notion is a concept of a 'fair trial' (cf. Section 35 (3) (k) of the Constitution of the Republic of South Africa). In essence, the notion of a 'fair trial' tends to run through all human rights treaties and conventions (Karton 2008). If the right to a fair trial is framed (as is the case with the South African Constitution) as inherently related or part and parcel of the right to be tried in a language that the accused person understands, it stands to reason therefore that for a trial to be considered fair, the associated rights, including language rights, must be guaranteed. Failure to provide these may contribute towards crippling procedural rights (Karton 2008:44), particularly if interpreting or translation services are characterised by distortive elements. Secondly, failure to uphold these rights (specifically language rights) may also lead to grave misgivings in relation to the accuracy of judicial truthfulness (ibid). Therefore, I submit, embracing the approach of equating language rights to human rights carries with it promising underlying principles which embrace the notion of equality and non-discrimination before the law. Associated spin-offs to this position contain, amongst others, the potential to circumvent any possible adversarial consequences related to compromising of language rights in the criminal justice system as all languages will, in fact, be accorded equal status and usage and thus operate without limitations. This stance is supported by one of Africa's renowned scholars of literature, Ngugi wa Thiong'o (2012:1), when arguing that,

One of the basic, most fundamental means of individual and communal self realisation is language. That's why the right to language is a human right, like all other rights enshrined in the constitution. Its exercise in different ways, communally and individually chosen, is a democratic right.

He further states that,

To have a mother tongue, whatever it is, and add another language to it is empowerment. But to know all the other languages and not one's own is enslavement. I hope Africa chooses empowerment over enslavement.

The fact that the language situation in South Africa remains unchanged post 1994, primarily in the judicial hierarchies from the bottom to the top, remains a serious challenge for Limited English Proficiency (LEP) South Africans. Cote (2005:13) makes a relevant observation that relates to the problem, arguing that,

[...] the generous provisions of s. 6 (of the Constitution) are tempered by concerns over practicality in the subsequent guarantees. This is especially true for s. 35(3) (k) where issues over practicality concerns have allowed for a situation where the pre 1994 privileged status of English and Afrikaans as the only languages in the country's courtrooms to continue. 
Undoubtedly, failure to appropriately address the deficits of the past in terms of the language question in the hierarchies of the judiciary means that South Africa will indeed be embracing enslavement over empowerment.

\subsection{Communicative competence of transpreters}

Kaschula and Anthonissen point out that communication in the legal process is limited to a specific legal register. These registers are restrictive and do not draw on shared knowledge of communicative principles, or an awareness of societal norms governing a wide range of other communicative events (1995:86). For the purpose of this paper, Rickheit, Strohner \& Vorwerg (2008) put the notion of communicative competence into perspective. Citing Hymes (1972), they point out that the notion of both (i) communicative competence - that is, the inferred ability to produce the observed performance - and (ii) communicative performance - that is the observable part - may be influenced by special cognitive and social factors. Following on this dichotomy (of which the former is the primary concern of this paper), it is worthy to note that the non-partisanship, lack of proper training and relevant qualifications and credentials of transpreters raise very important questions that are associated with the selected criteria of communicative competence in this discussion, namely, amongst others, (i) accuracy and (ii) objectivity in translation and interpreting practices in relation to the ET trial and judgement. The issue that gets immediate treatment here relates to accuracy, which according to Hussein (2011:26) "[...] is manifested in the absence of errors, omissions, modifications or embellishments in rendering the speaker's words". Karton's (2008:8) view of accuracy is somewhat consistent with Hussein's (2011) when Karton points out that "[...] inaccurate interpretation does encompass instances such as those in which a word is improperly rendered into its grammatical equivalent, or a concept that is clear in one language and culture has no equivalent in another". Another important observation is made by Steytler (1993) when he states that "[...] poor translation routinely occurs and will continue to occur, because the structural influences on interpreters militate against the adequate performance of their task". Unfortunately, the same could be said about the transpreters during the handling of the ET trial within a trial (cf. S v Mahlangu and Ndlovu 2010 (2) SA CC70).

Transpreters are supposedly instrumental in a language event that connects language, law and crime including, for example, the communication of rights and providing of translation services for sworn statements. Apart from this exercise being confrontational with even more complexities and sophistication, and tapping from the transpreters' cognitive juggling online, it is also worth stating that transpreters commit to this duty despite not being officially sworn in - which I may have been consciously binding, considering the sensitivity and delicacy of their translation and interpreting assignment.

Although it may not be easy to know or detect inaccuracies that go into the record from the entry point of statement taking, the possible consequences of such inaccuracies might be implicit or explicit in the outcome or judgement. Reference is made to Extract 3 below:

\section{Extract 3}

[...] the impromptu examination conducted by Mr Majavu, who at that stage handled the cross-examination on behalf of Accused 2 supposedly to gauge the interpretational skills of Reserve/Constable Mthembu must be viewed in its proper perspective. Firstly, although Mr Majavu is adept in the use of the Afrikaans language, I truly at times, had difficulty grasping Mr Majavu's Afrikaans pronunciation. No wonder Reserve/ 
Constable Mthembu had difficulty understanding him. Secondly, having regard to the fact that the impromptu test was performed in the tense atmosphere of a court, Reserve/Constable in fact did relatively well in the circumstances. Reserve/Constable Mthembu's evidence was not that his interpretation would be flawless, but that he will interpret to the best of his ability. And that, I believe, he succeeded in doing so (2010: 26).

In dealing with the analysis of the accuracy and objectivity issues in relation to Reserve/Constable Mthembu's interpretation in the ET trial (as highlighted in Extract 3), Rock's (2004:285) view bears some relevance in this regard:

Witness statements are taken in specific contexts; for example within particular power relations and using specific processes of production, such as cognitive interviewing. When statements are used, however, these contexts and processes are rarely mentioned - for example, juries are not typically urged to consider what questions might have been asked during text construction.

In this regard, Rock's view is quite akin to the issues raised in the ET trial (cf. Extract 3). Although it would seem that inadequacy of translation/interpretation skills is not recognised by the judge which, in my view, has potential for the denial of a fair trial upon the accused person/s, it is evident that the transpreter's (in the name of Reserve/Constable Mthembu) communicative competence is questionable. As such, the probability of inaccuracy is quite high. This reality of this situation is also observed by the South African Press Association (SAPA 2012), cited here:

The boy's lawyer, Zola Majavu, tried to show how information could be misinterpreted or misunderstood. He asked Reserve Detective Constable Emmanuel Mthembu to translate phrases from Afrikaans to Tswana, as he would have done when he explained the rights of the youth to him and his mother before the teenager pointed out the crime scenes. Mthembu struggled to do so correctly at all times. When he translated incorrectly, the court translator explained that Mthembu's version was not verbatim, but a simplified version. Majavu was questioning the accuracy of Mthembu's translations between Lieutenant Colonel Frans Jacobs, the youth and his mother, after Terre'Blanche's murder.

The judge might have done his best to defend the justice system, and this is well understood as his credibility as well as that of the legal system is primarily dependent upon his judgement. But, in doing so, the question remains as to whether he has acted in the full interest of justice. This is an important question that goes beyond the scope of this paper. However, if this paper follows both Hussein's (2011) and Karton's (2008) definitions of "accuracy", which I believe it should embrace in this context, it goes without saying that the judgement is surrounded by an element of controversy. The reason for this is, amongst others, that failure to commit fidelity to the original tends to result in translation casualties, and this on its own becomes an infringement of justice - as has been contested in this paper. 
Morris (1995:6) makes a valid point when arguing that,

Thoughtful translators and interpreters can see where to keep and where to adapt form, and what the effect will be of failing to do so. They know how to use the resources of the target language and society to exploit, and not to offend against the traditions and imaginative possibilities of that other language. They know... Yet the hard-won knowledge that they possess is virtually invisible to monolinguals and to superficial bilinguals [...] Such persons may otherwise be splendidly and expensively educated, as are lawyers and judges, who can cut things fine in their language.

This is certainly a tall order but the fundamental question is whether the South African Police Service has reached this level of sophistication in terms of infrastructure and human resources. The general evaluation of the judgement suggests a rather negative response to this enquiry.

In dealing with objectivity, defined by Hussein (2011:26) as "[...] prevailing by insuring that the interpreter [transpreter - MKR] has no personal interest in the outcome of the case or is biased with or against the speaker", within the workings of the law enforcement agency, reference is made to the judgement in Extracts 4 and 4.1.

\begin{abstract}
Extract 4
[...] much cross examination was directed at contradictions in the police statement. Some of the police witnesses were heavily criticised for the manner they recorded the statement and the lack of detail in those statements. While some statements lacked clarity and precision it cannot be said that the police witnesses deliberately set out to mislead the court $[\ldots .$.$] There was simply no reason for the policemen to fudge$ their evidence or to falsely implicate the accused (2012:40).
\end{abstract}

\title{
Extract 4.1
}

Police statements and statements obtained from witnesses by the police are notoriously lacking in detail, are inaccurate and often incomplete [...] It would be absurd to expect a witness to say exactly in his statement what he will eventually say in court (2012:41).

Taking a closer look at the recording and formation of sworn statements in his research, Braz (2010:10) presents some background in relation to police interrogation and interviews. He asserts that "in police interrogation, the police goal is to obtain information from the suspect that ultimately will help the investigation of a crime". In order to achieve this exercise, the transpreters, who have a more authoritative status, make use of linguistic strategies that may restrain the suspect's contribution to the interaction (ibid). Eades (2010:165) asserts a somewhat similar view by referring to Berk-Seligson (2008) who states that "[...] the potential for miscarriage of justice rises substantially when the suspects being investigated are not fully proficient in English, and rises even higher when the police officials who themselves are not fluent in the language of the detainee conduct interrogations in that language". Over and above this so-called inherent power and control, conflict of interest is essentially inevitable in the practice of transpreters in which allegiance, loyalty and sense of duty is automatically placed more, or solely, on the system rather than on the members of the public who, in most cases, are 
accused persons or witnesses. With these formidable arguments, and in the light of questionable opinions contained in the judgement, it stands to reason that the notion of 'objectivity', as supposedly upheld by transpreters in the ET trial, is also questionable. Furthermore, although there seems to be critical questions in relation to the notion of transpreters and their competence, these issues raise grave misgivings as they illustrate classic examples in which the notion of inequality is perpetuated through deliberate failure to provide competent and qualified translation/interpreting within the South African criminal justice system.

\subsection{Asymmetry in the police interaction}

In dealing with the notion of asymmetry in the police interaction, Van Charldop's (2011) investigation of the issue is quite interesting. Apart from considering a contradictory setting in which the transpreters and the suspect have different roles to accomplish, she outlines various instances of asymmetries that are worthy to note. One, the police officer has a commitment and responsibility to further the interests of the criminal law process against the suspect who is the layperson and thus responsible to himself. Two, the police officer is privileged to have access to a body of knowledge about the suspect whereas the suspect has little or no information about the police officer. Three, the setting of the interrogation room displays an asymmetry which entitles the officer to be in control of resources through which information is acquired, whereas the suspect has no entitlement whatsoever. Four, on the one hand, the institutional setting is organised in such a way that the police officer takes control of the interaction by asking questions and formulating the record from the spoken interrogation. On the other hand, the suspect is expected to provide answers to these questions. Five, the suspect is under arrest and may be in custody; s/he may have rights but these are limited. This, according to Van Charldop (2011), is the biggest asymmetry of all.

What seems to be missing in Van Charldop's conceptualisation, which I find equally imperative to her biggest asymmetry, is the notion of 'gratuitous concurrence' which tends to run through most of the sections of the ET judgement. In deconstructing this notion as it relates to the ET judgement, Eades (2000:14) states that "gratuitous concurrence is the tendency to agree with the questioner, regardless of whether or not you actually agree with, or even understand". Furthermore, she points out that the concept is particularly common where the questioner is in a position of authority, and when the questioner asks a series of yes/no questions. The problem with this type of communication pattern is that it draws witnesses into giving illogical evidence (Eades 2000). Reference is made, through the following extracts, to the judgement:

\section{Extract 5}

[...] he asked the accused whether they would be willing to provide the clothes they were wearing for DNA purposes and both agreed. Cons. Modise stated that the accused spoke freely and voluntarily to him without being influenced. They were in their sound and sober senses. He spoke in Setswana to the two accused and there was no room for misunderstanding (2010:9).

\section{Extract 5.1}

He read the full contents of the pointing-out statement into the record. According to the statement Accused 1 admitted his direct involvement in the robbing and killing of the deceased. I should mention that after a trial within a trial, I ruled that the pointing-out statement made by Accused 1 was admissible (2010:14). 


\section{Extract 5.2}

He readily led the police to the scene of the crime. He declared his involvement in the killing of the deceased to anyone who cared to listen [...] (2010:16).

\section{Extract 5.3}

At no stage did either Accused 2 or his mother complain that they did not understand him or that they did not understand the proceedings. Indeed, the mother told Lt Col Jacobs and Reserve/Const Mthembu that she understood Afrikaans well (2010:26).

\section{Extract 5.4}

The test really is: Did Accused 2 and his mother understand the proceedings as interpreted? They both confirmed verbally and in writing that they did, Accused 2 by signing the document and his mother by placing her thumb print on the document (2010:27).

\section{Extract 5.5}

He informed them of their constitutional rights and they both indicated that they understood (2010:27).

It is my submission that some of the patterns of language use and communication within the circles of the judiciary and the criminal justice system are not only culturally and linguistically biased but they are uncompromisingly colonial and, as such, tend to alienate those whose English and Afrikaans proficiency is low or non-existent from the mainstream justice. Central to and reinforcing this reality, among others, is the asymmetry in the police interaction which is structured to entrench some level of control and power. Specifically, there is an overwillingness of the accused person or witness to concur with the questioner (as shown in the ET judgement) who is in the capacity of authority status, even though comprehensibility is thin or nil. The ET trial is a classic example of this situation. Suffice it to say that from the initial stage this may seem to spare the accused person or witness from the embarrassment of seeming unintelligent, yet eventually it may bear some potential for adversarial consequences for the accused person or witness.

In terms of the South African experience, with specific reference to the ET trial and judgement, it could be argued that gratuitous concurrence is one of the important communication patterns and powerful instruments meant to disadvantage the accused persons or witnesses. Its potential to violate the structure of thinking and create deliberate confusion seems to be its primary goal, and poor South Africans who end up embroiled in the criminal justice, whose English or Afrikaans proficiency is low or non-existent, are particularly susceptible to this confrontation.

\subsection{Implications of the ET trial within a trial in the context of law enforcement in South Africa}

\subsubsection{Legal recognition linguistic and cultural differences}

The ET trial has profound implications for the South African multilingual and multicultural context setup. The fact that the languages spoken and understood by ordinary people (African languages) are at odds with those utilised by the criminal justice system (English and Afrikaans) is an issue of serious concern, and has serious implications for the accused persons who become embroiled in criminal activities. Some studies (cf. Kaschula \& Ralarala 2004; Kaschula \& 
Anthonissen 2005) have considered the issue of language awareness within the administration of justice in South Africa. However, these do not seem to have had an impact in sensitising the judiciary. In view of this position, a rigorous debate on issues relating to the recognition of African languages and cultures, as a matter of policy, in the framework of enforceable language rights in the criminal justice system could be one of the more viable solutions.

\subsubsection{Balance of power and function of the system}

It seems to be a common tendency that power obscures sanity and impartiality within the system. The reason for this statement is that some of the legal matters, particularly statement taking or record construction, are dealt with within certain power relations (Rock 2004), and the ET trial has proven this fact. Although this might be an institutional culture which might work in favour of the state or against the accused persons or vice versa, either way is not desirable in a democracy as this has the potential to negatively affect the delivery of justice. For this reason it is not unreasonable to initiate the interest of the law enforcement agency to explore viable means and ways of seeking information and acquiring evidence that could support social justice and prevent the notion of bias. In other words, rethinking the current method of statement taking or record construction in the light of the untenable criticism leveled against the police service seems inevitable.

\section{Conclusion}

This paper has elected to utilise a single case (the ET trial) as its unit of analysis, taking into account fundamental issues such as (i) language rights, (ii) communicative competence of transpreters, (iii) asymmetry of police interaction, along with (iv) the implications of this particular case for the South African criminal justice system. In relation to language rights, this paper has argued that access to justice is, amongst others, dependent on the accessibility of the languages that are utilised in the criminal justice system, that is, the right of a language and right to a language in Makoni et al.'s (2008) terms. Furthermore, equating language rights to human rights with the necessary enforcement mechanisms will give prominence to this notion, and thus amount to the advancement of the principle of a fair trial. This view is also echoed by Steytler (1993:221) who suggests that "rights, including language rights, will thus remain paper tigers if there is no clear understanding of the social structures which tend to undercut them and attempts are not made to address those very structural influences".

With reference to the notion of 'communicative competence', this paper has shown that transpreters lack, to a certain degree, the necessary comprehension and comprehensibility which could account for accuracy and objectivity in the process of statement taking or record construction. As noted earlier in the discussion, this knowledge gap has far-reaching consequences in as far as the delivery of justice is concerned. The recognition by the legal system of the complexity of the interface between language and the law, particularly statement taking, and the need for effective communication cannot be over-emphasised. This would, in turn, reinforce the training and deployment of skilled and qualified staff to deal with this specialised function. The notion of 'gratuitous concurrence', as a matter of asymmetry in the police interaction, has been an important communication pattern inherent in the ET trial. This paper has shown its unfair linguistic manipulation upon those who lack the knowledge of the languages of the criminal justice system. As a way of circumventing this shortcoming, audiorecording of statements may not be an unreasonable recommendation. 
Apart from its general academic contribution, the paper has also been concerned with key additional academic areas such as forensic linguistics, translation studies and interpreting studies. This provides traction in terms of demonstrating the significance of an interdisciplinary approach towards initiating the interest of linguists and legal minds in addressing and understanding language, culture and statement taking or record construction related challenges within the judiciary and the law enforcement agency.

\section{Acknowledgments}

I am grateful to the anonymous reviewers who showed a keen interest in this work. I am also indebted to the following colleagues for assisting me, in their various ways, in order to put this manuscript together: Adv. Norman Arendse, SC; Prof. Russell Kaschula; Prof. Diana Eades; Judge Tandazwa Ndita and Dr Jenny Wright. I take full and sole responsibility for this paper.

\section{References}

Adler, R. \& G. Rodman. 2006. Understanding human communication. Oxford: Oxford University Press.

Berk-Seligson, S. 2008. Judicial systems in contact: access to justice and the right to interpreting/translating services among the Quichua of Ecuador. Interpreting 10(1): 933.

Braz, A. 2010. A preliminary study of police interrogation in Spain. PhD Dissertation Proposal. Spain: Universitat Pompeu Fabra.

Commission for the Promotion and Protection of the Rights of Cultural, Religious Linguistics Rights of Communities Act, Act No. 19 of 2002.

Cooke, M.S. 1995. Understood by all concerned? Anglo/Aboriginal legal translation. In M. Morris (ed.) Translation and the Law. American Translators Association Scholarly Monographs Series. Vol. VIII. Amsterdam: John Benjamin's Publishing Company. pp 37-66.

Constitution of the Republic of South Africa, 1996.

Cote, D. 2005. The right to language use in South African criminal courts. Unpublished LLM dissertation.

Coulthard, M. \& A. Johnson. 2007. An introduction to forensic linguistics: Language in evidence. London: Routledge.

Eades, D. 1996. Legal recognition of cultural difference in communication: The case of Robyn Kina. Language \& Communication 16(3): 215-227.

Eades, D. 1997. Language in court: The acceptance of linguistic evidence about Indigenous Australians in the criminal justice system. Australian Aboriginal Studies 1: 15-27.

Eades, D. 2000. Aboriginal English in the courts: A handbook. Brisbane: Queensland Law Society.

Eades, D. 2002. 'Evidence given in unequivocal terms': Gaining consent of Aboriginal young people in court. In J. Cotterill (ed.) Language in the legal process. London: Palgrave Macmillan. pp. 161-196.

Eades, D. 2004. Understanding Aboriginal English in the legal system: A critical sociolinguistics approach. Applied Linguistics 25(4): 491-512.

Eades, D. 2010. Sociolinguistics and the legal process. Toronto: Multilingual Matters.

Fairclough, N. 1989. Language and Power. London: Longman.

Geldenhuys, T. 2001. Language policy of the South African police service. In K. Deprez, T. Du Plessis \& L. Teck. (eds.) Multilingualism, the judiciary and security services: Belgium, Europe, South Africa, Southern Africa. Pretoria: Van Schaik. 
Hussein, N. 2011. Legal interpreting in the criminal system: An exploratory study. Unpublished $\mathrm{PhD}$ dissertation. Leicester: De Montfort University.

Karton, J. 2008. Lost in translation: International criminal tribunals and the legal implications of interpreted testimony. Vanderbilt Journal of Transnational Law 41(1): 1-54.

Kaschula, R \& C. Anthonissen. 1995. Communicating across cultures in South Africa: Towards a critical language awareness. Johannesburg: Witwatersrand University Press.

Kaschula, R. \& M. Ralarala. 2004. Language rights, intercultural communication and the law in South Africa. South African Journal of African Languages 24(4): 252-261.

Komter, M. 2002/2003. The construction of records in Dutch police interrogations. Information Design Journal + Document Design 11(2/3): 201-213.

Linfoot, K. 2007. Forensic linguistics, first-contact police interviews, and basic officer training. Unpublished $\mathrm{PhD}$ dissertation. Florida: University of Florida.

Lubbe, H. 2008. Taalregte en die regspraak. SPILPLUS 36: 67-87.

Makoni, S., P. Watson, M. Pienaar \& T. Moyo. 2008. Language in education policy. Unpublished Report. Commission for the Promotion and Protection of Cultural, Religious and Linguistic Rights of Communities. Johannesburg.

Moeketsi, R. 2002. Understanding the other: A case of mis-interpreting culture specific utterances during alternative dispute resolution. In J. Cotterill (ed.). Language in the legal process. New York: Palgrave Macmillan. pp. 196-212.

Morris, M. 1995. (ed.) Translation and the law. American Translators Association Scholarly Monographs Series. Vol. VIII. John Benjamin's Publishing Company. Amsterdam. pp. $1-12$.

Ngugi Wa Thiong'o. 24 June 2012. Speaking my language. Sunday Times (Review).

Pan South African Languages Board Act No 59 of 1995.

Rickheit, G., H. Strohner \& C.Vorwerg. 2008. The concept of communicative competence. In G. Rickheit and H. Strohner (eds.) Handbook of Communication Competence. Berlin: de Gruyter. pp. 15-62.

Rock, F. 2007. Communicating rights: The language of Arrest and Detention. Palgrave: Basingstoke.

Shah, S., I. Rahman \& A. Khashu. 2007. Overcoming language barriers: Solutions for law enforcement. New York: Vera Institute of Justice.

South African Press Association (SAPA). 2012. Translation queried in Terre'Blanche case. [Online] Available: http://www.news24.com/SouthAfrica/News/Translation-queriedin-TerreBlanche-case-20120201 [Accessed 18 July 2012].

South African Languages Bill, 2011.

Steytler, N. 1993. Implementing language rights in court: The role of the court interpreter. South African Journal on Human Rights 9: 205-222.

S v Kimbani 1979 (3) SA 339 (E).

S v Mahlangu and Ndlovu 2010 (2) SA CC70.

Waterhouse, K. 2009. Interpreting criminal justice: A preliminary look at language, law and crime in Ireland. Judicial Studies Institute Journal 2: 42-75.

Van Charldorp, T. 2011. The Coordination of Talk and Typing in Police Interrogations. Crossroads of Language, Interaction and Culture 8(1): 61-92.

Van der Merwe, I. \& J. Van der Merwe (eds.) 2006. Linguistic atlas of South Africa: Language in space and time. Stellenbosch: SUN PreSS.

Van Dijk, 2003. Critical discourse analysis. In D. Schiffrin, D. Tannen \& H.E. Hamilton (eds). The handbook of critical discourse analysis. Oxford: Blackwell. pp. 352-371. 